\title{
DISTRIBUTION OF CALORIFIC VALUE BY COKE SIZE CLASS
}

(C) I.V. Miroshnichenko, V.V. Gavrilyuk (PJSC "AZOVSTAL IRON \& STEEL WORKS", 87500, Mariupol, Leporskogo st., 1, Ukraine), D.V. Miroshnichenko, Doctor of Technical Sciences (National Technical University "Kharkov Polytechnic Institute", 61002, Kharkov, Kirpicheva st., 2, Ukraine), I.V. Shulga, PhD in technical sciences (State Enterprise "Ukrainian State Research Coal Chemical Institute (UKHIN)", 61023, Kharkov, Vesnina st., 7, Ukraine)

As is known, the specificity of the layered coking process causes the development of fracturing, which determines the formation of the granulometric composition of the coke. The article presents and analyzes data on the physicochemical properties of coke of various size classes. The expediency of studying the values of the calorific value for different classes of the size of blast furnace coke has been substantiated. For this purpose, ramp coke was taken from batteries that were significantly different in size. In particular, coke oven battery I has almost twice the useful volume of coking chambers and, accordingly, the design capacity than coke oven battery II. In addition, the height of the chambers of coke oven battery I is $7000 \mathrm{~mm}$, and that of coke oven battery II is $4300 \mathrm{~mm}$. The above circumstances must be taken into account when evaluating the heat of combustion of various size classes of blast furnace coke. The composition of the investigated charge consisted of classic grades of coals, which are characterized by their inherent set of quality indicators. The charge for battery I was characterized by a lower burst pressure.

It is shown that the value of the highest calorific value of wet quenching blast furnace coke undergoes significant changes depending on the size. Size classes less than $25 \mathrm{~mm}$ are characterized by maximum values of the gross calorific value, which reach 33.0 $M J / k g$ and more.

The level of "readiness" of coke, expressed by the value of the yield of volatile substances and the actual density of the coke, significantly affects the value of the highest calorific value. Less "finished" blast furnace coke is characterized by higher values of the gross calorific value for all particle sizes.

It is concluded that the value of the highest calorific value of blast furnace coke can serve as a criterion (in addition to those already available) for assessing the degree of "readiness" of blast furnace coke.

Keywords: coal, coke, coke size classes, degree of readiness, heat of combustion.

Corresponding author Miroshnichenko I.V., e-mail: igor.miroshnichenko@azovstal.com.ua 